\title{
HEAT STRESS EFFECTS ON GROWTH AND DEVELOPMENT IN THREE ECOTYPES OF VARYING LATITUDE OF ARABIDOPSIS
}

\author{
E. KIPP \\ Pace University Department of Biology and Health Sciences 1 Pace Plaza \\ NewYork, NY 10038 \\ (phone: 212-346-1373; fax: 212-346-1256) \\ e-mail: ekipp@pace.edu \\ (Received $22^{\text {nd }}$ October 2006 ; accepted $23^{\text {rd }}$ October 2007 )
}

\begin{abstract}
Global temperatures have increased $0.6{ }^{\circ} \mathrm{C}$ over the past century; however regional temperatures have shown greater fluctuations. Since local environmental conditions vary along latitudinal clines, latitude has become an essential component in projecting plant response to warming. Three ecotypes of Arabidopsis were selected from varying latitudes in order to investigate heat stress within an ecotype and project potential effects across a gradient. Control and heat stressed groups received 12 hour photoperiods. Control plants were grown at $2.7 / 22.7^{\circ} \mathrm{C}$ day/night mean temperatures and heat stressed plants were grown at $22.7 / 29^{\circ} \mathrm{C}$ day/night mean temperatures. Plants were quantified and harvested 35 days after sowing. The number of rosette leaves, flower buds, and fruits resulted in significant differences both between control and heat stressed plants of the same ecotype and also across ecotypes. Heat overwhelmingly resulted in a quantitative decrease across all parameters, including overall plant size, with the exception of flowers in ecotype 902. And even though the heat stressed 902 plants flowered while the control group plants did not, neither produced fruit. Thus, heat adversely affects growth and development as well as reproductive success in Arabidopsis.
\end{abstract}

Keywords: Arabidopsis, global warming, heat stress

\section{Introduction}

Concern about temperature increases on a global level has sparked research in quantifying plant responses to heat stress. This has become of particular interest to a wide range of scientists and disciplines as evidence suggests that increased temperatures such as that associated with global warming will have widespread adverse effects on species diversity [7] [19] [30], food-web and ecosystem structuring [10] [5] [19], dominant vegetation [10] [25], plant physiology and development [18] [26] [17] [20] [9], climate [15] [30], and phenology [16] [30]. As a result, some governments have become more involved in setting up panels to review environmental trends, explore alternative energy options, and curb fossil fuel consumption.

Environmental and ecological changes due to temperature increases such as those associated with global warming have been well documented. Global warming is a twopart problem that is directly related to ozone depletion and greenhouse gas accumulation. It is characterized by rising atmospheric levels of greenhouse gases such as carbon dioxide coupled with an increase in average global temperatures. And while global temperatures have increased by $0.6{ }^{\circ} \mathrm{C}$ over the past 100 years [30] [24], the majority of this documented increase has taken place from 1976 to the present [30]. One must bear in mind, however, that reporting an average global temperature increase tends to oversimplify the extent of global warming, as more marked temperature changes are noted on a regional scale [10] [19] [25] [15] [30].

Many studies have imposed heat stress on plants in order to quantify the thermal stress response. Research clearly indicates a heightened sensitivity of plants to an 
increase in carbon dioxide and temperature with respect to respiratory rate, propagule size, production, and viability, and biomass production [22] [1] [21]. Further studies have also shown altered photosynthetic rates linked to an increase in temperature [1] [14] [21].

It was determined that heat adversely affected pollen and anther development in Lycopersicon esculentum (Solanaceae), the tomato, which, in turn, contributed to a decreased fruit set [18[ [26]. Work with another crop plant, the common bean Phaseolus vulgaris (Fabaceae), showed that heat applied prior to anthesis resulted in pollen and anther development abnormalities [20]. Flax, Linum usitatissimum, (Linaceae), is another financially viable plant that is detrimentally affected by heat stress [6]. Heat was found to affect the reproductive capacity of L. usitatissimum when applied after floral initiation. The fruits (boll) weighed less than the fruits of control plants and were three times more likely to have malformed, sterile seed [6]. Since these are economically valuable plants, reduced crop yields may result from increasing temperatures.

Climate changes, linked to environmental warming, may significantly alter air and soil temperatures as well as soil water content [14]. Precipitation levels have been shown to have direct effects on species, as water stress is an important factor determining species distributions and diversity [15]. The distribution and diversity of terrestrial vegetation in particular, is most reliant on a combination of both temperature and water availability [11].

Overall, global climate change models predict a $2-6^{\circ} \mathrm{C}$ temperature increase over the next 100 years [11] [19] [30] [24]. Overwhelmingly, anthropogenic activity has been indicated to have impacted the natural balance of biotic and abiotic factors contributing to the world's ecosystems. Since plants are sessile organisms, they are, for the most part, unable to relocate in the face of inhospitable environmental conditions created in large part by anthropogenic activity. Because global warming is believed to cause a variety of heat-related stress responses in plants that may alter their ability to survive, the following research was conducted to help quantify plant responses to global warming.

\section{Materials and methods}

\section{Background on Arabidopsis thaliana}

Controlled laboratory experiments were conducted using Arabidopsis thaliana, a plant in the Brassicaceae or mustard family. A. thaliana, often referred to simply as Arabidopsis, is widely used in research for a great many reasons and has quickly become a model organism across plant biology and genetics. Since space, time, and money are all considerations when choosing a research subject, A. thaliana lends itself particularly well as it is easy and inexpensive to grow, grows well in small spaces, only reaches about $25 \mathrm{~cm}$ at maturity, and completes its life-cycle within 6-8 weeks.

A. thaliana is a small herbaceous rosette annual and one of about 3,000 species of the Brassicaceae, a family of dicotyledonous plants. It inhabits a wide range of ecological and geographical regions and is commonly found throughout the Americas, Europe and Western Asia, northern Africa and East Asia. While it is most common in temperate North America, it is suspected to have originated in Eurasia. The ideal temperature range for A. thaliana is $16-25^{\circ} \mathrm{C}$ while $22-23{ }^{\circ} \mathrm{C}$ is considered optimum. 
A. thaliana can grow in a photoperiod ranging from 8-24 hours, however, Weigel et al. (2002) suggest that $>12$ hour photoperiods tend to accelerate the reproductive cycle and $<12$ hours favors vegetative growth. Koornneef et al. (1998) further determined that flowering was promoted by long photoperiods and delayed during short photoperiods. Hence, as flowering time is accelerated under long photoperiods, the resulting tradeoff is a reduction in vegetative growth. Optimum humidity should be between $25-75 \%$.

The Arabidopsis flower is complete, perfect, and self-compatible. The flower, typical of Brassicaceae, has four sepals and four petals. The androecium generally consists of six longitudinally dehiscent stamens, four upper and two lower, although some have been documented to contain only four or five stamen in total. The gynoecium is superior, the style is reduced and the base is formed of two fused carpels. The fruit type in Arabidopsis, as is typical of Brassicaceae, is the silique.

\section{Origin of germplasm}

Seed stock of three ecotypes (ecotype Cvi-O stock number 902; ecotype Est-O stock number 1148; and ecotype Col-O stock number 6673:) representing different latitudes $(\mathrm{N} 15, \mathrm{~N} 58$, and N38, respectively) were obtained from the Arabidopsis Biological Resource Center (ABRC). Since an ecotype is a population within a species that has developed distinct physiological characteristics in response to a specific set of environment conditions. These characteristics will persist even if individuals of the population are moved into a different environment.

ABRC was established in 1991 at The Ohio State University (http://www.biosci.ohio-state.edu/ plantbio/Facilities/abrc/abrchome.htm). ABRC seed stock was accessed via The Arabidopsis Information Resource (TAIR) web site (http://www.arabidopsis.org). Table 1 lists stock numbers and corresponding origin, latitude, elevation, habitat and other relevant information for all three ecotypes.

Table 1. Summary of information for the three ecotypes of A. thaliana used in this study. Compiled from The Arabidopsis Information Resource (TAIR). Localities and habitats of seed stock origin

\begin{tabular}{|c|c|c|c|c|c|c|c|}
\hline $\begin{array}{l}\text { Stock } \\
\text { No. }\end{array}$ & Name & $\begin{array}{l}\text { Abb. } \\
\text { Name }\end{array}$ & $\begin{array}{l}\text { Country/ } \\
\text { Location }\end{array}$ & $\begin{array}{c}\text { Latitude/ } \\
\text { Longitude } \\
\text { (min) }\end{array}$ & $\begin{array}{l}\text { Altitude } \\
\text { (m) }\end{array}$ & Habitat & Description \\
\hline 902 & $\begin{array}{l}\text { Cape Verdi } \\
\text { Islands }\end{array}$ & Cvi-O & $\begin{array}{l}\text { Cape } \\
\text { Verdi }\end{array}$ & N 15, W 23 & 1200 & Rocky wall & $\begin{array}{l}\text { Serrated lf } \\
\text { margins, height } \\
=30 \mathrm{~cm}\end{array}$ \\
\hline 6673 & Columbia & Col-O & $\begin{array}{c}\text { USA/ } \\
\text { Columbia }\end{array}$ & N 38, W 92 & $1-100$ & - & $\begin{array}{l}\text { (slightly) } \\
\text { Serrated lf } \\
\text { margins, height } \\
=25-35 \mathrm{~cm} .\end{array}$ \\
\hline 1148 & Eastland & Est-O & $\begin{array}{l}\text { Russia/ } \\
\text { Eastland }\end{array}$ & N 58, E 23 & $100-200$ & Sandy hill & $\begin{array}{l}\text { Light green } \\
\text { rosette, glabrous } \\
\text { lvs, height }=25- \\
35 \mathrm{~cm} .\end{array}$ \\
\hline
\end{tabular}




\section{Germplasm selection process}

Local environmental conditions such as latitude and altitude can affect plant growth [13] [2] [28]. High altitude and latitude regions are expected to be especially sensitive to temperature increases [24]. Additionally, plants grown at higher altitudes or geographical latitudes have been documented to be more tolerant of UV-B radiation [8]. Therefore, the three ecotypes were selected to represent high, mid, and low range latitudes. In doing this, research findings presented here can help describe the patterns of variation in growth and overall plant size across a latitudinal cline.

\section{Seed germination}

Petri dishes were fitted with Whatman brand filter paper cut to size and wetted with tap water $\left(\mathrm{H}_{2} \mathrm{O}_{[\mathrm{t}]}\right)$. Separated by ecotype, seeds (of the three ecotypes) were placed onto the wetted filter paper, covered with the Petri dish top, and placed into a $4^{\circ} \mathrm{C}$ refrigerator to initiate the process of cold germination. The stages of germination were observed using a dissecting microscope after 2, 3, and 4 days. At day $=4$, the roothypocotyl transition zone was obviously extended from the swollen seed coat and deemed ready for planting.

\section{Sowing seed}

On day $=4$, the three different ecotypes were planted in Park's Starts brand styrofoam blocks measuring 2 1/2" x 3" x 6," obtained from Connecticut Valley Biological Supply Company. Each block contained 18 cells fitted with peat moss plugs. The peat moss was held together with a natural biodegradable binder and was both pasteurized and pre-moistened by the manufacturer. Two full blocks of 18 were planted for each ecotype. The initial sowing density was 3 seeds per cell. A Leica Zoom 2000 dissecting microscope and nickel-plated steel forceps were used in order to plant three seeds per preformed hole in each of the cells. Plants were thinned three days after sowing. Only one plant per cell was retained, for a total of $n=36$ seedlings for each of the three ecotype and a grand total of $n=108$ seedlings for the experiment.

\section{Growing conditions}

Since ultraviolet radiation can increase leaf temperature $5{ }^{\circ} \mathrm{C}$ above ambient temperatures (Frohnmeyer, 2003), the experimentally heat stressed Arabidopsis plants received a temperature of $29{ }^{\circ} \mathrm{C}$, representing an increase of about $5{ }^{\circ} \mathrm{C}$ above the upper limit of optimum growth temperature for Arabidopsis.

The experimental plants were placed on the growth cart on top of plastic grating which was in turn set atop $1 / 2$ pound of pebbles, average diameter $13 \mathrm{~mm}$, into each of two 21" x 10" (internal measurement) plastic trays. The water $\left(\mathrm{H}_{2} \mathrm{O}_{[\mathrm{t}]}\right)$ level was kept at or just above the pebble line. Each styrofoam block of plants was fitted with plastic film similar to saran wrap which extended down the entire height of the blocks for the first 10 days. The cart itself was fitted with a plastic tarp in order to maintain a higher than ambient humidity.

Night treatments additionally received a $100 \%$ cotton breathable tarp, detailed below, in order to create complete darkness and compensate for any drop in temperature on the cart overnight. Experimental humidity was maintained at an average of $55.24 \%$ on the 
growth cart both day and night; the mean temperature was $22.7^{\circ} \mathrm{C}$, both day and night for 35 days, the duration of the experiment.

Indoor Garden, 52" X 23" X 74", purchased from Fisher Scientific. The plants received an initial day light length of 24 hours for three days, prior to thinning, to ensure the seeds were established before subjecting $1 / 2$ to heat stress. GrowLab II light was provided by two 40 Watt Gro-Lux wide-spectrum Osram Sylvania Inc. bulbs placed 20 inches away from the top of the styrofoam blocks. Initial lumen for the bulbs was 1,700 lumens.

After this initial three day period of $24 \mathrm{~h}$ day, the day length was held at 12 hours (12 $\mathrm{h}$ day) and night length 12 hours (12 h night) for 35 days, the duration of the experiment in order to minimize favoring elevated photoperiods in one direction.

One block of cells for each ecotype (for a total of 3 blocks in each of 2 sets) received daily heat stress treatments of $29^{\circ} \mathrm{C}$ for the 12-hour periods. During this same 12 hour period, the control set (no heat treatment) remained on the plant growth cart with the Gro-Lux lights turned off and a 14-15oz, 100\% breathable cotton canvas tarp, 7' x 9' placed over the cart to create darkness. Heat stressed plants were placed into a low temperature Fisher Scientific Isotemp brand incubator, model $146 \mathrm{E}$, set to $29^{\circ} \mathrm{C}$ with a manufacturer's temperature guarantee constancy of $+/-0.2{ }^{\circ} \mathrm{C}$ and a uniformity temperature reading of $+/-1^{\circ} \mathrm{C}$.

For the duration of the experiment, temperature was maintained at a mean of $22.7^{\circ} \mathrm{C}$ on the growth cart, $29{ }^{\circ} \mathrm{C}$ in the growth chamber, and a mean humidity of $55.24 \%$ on both the cart and in the chamber. Therefore, the control set received $22.7 / 22.7^{\circ} \mathrm{C}$ mean day/night temperature with a 12 hour photoperiod, while the heat stressed set received $22.7 / 29^{\circ} \mathrm{C}$ mean day/night temperature with a 12 hour photoperiod. During the $12 \mathrm{~h} \mathrm{~d}$, both control and heat stress sets were grown next to each other. In order to prevent a loss of genetic integrety, cross-pollination was avoided by covering flower buds with pollination bags.

\section{Parameters observed}

Both heat stressed and control plants for each ecotype were assessed 35 days from sowing the seeds. Observations taken were: (1) number of rosette leaves, (2) length of main bolt, (3) length of additional bolts, (4) number of flower buds (5) number of flowers, and (6) number of fruits(Figures 1-6). At the end of the experiment, at day = 35 , all plants were uprooted and measured from shoot tip to root tip. Additionally, the mean plant length was calculated for each treatment within each ecotype (Figure 7).

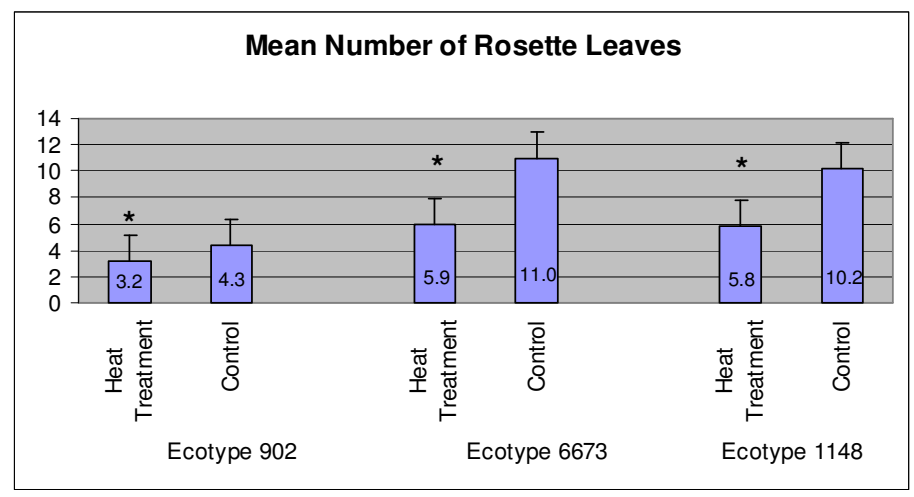

Figure 1. Mean number (+/- SD) of rosette leaves plotted for heat treated and control plants for each of the three ecotypes. 


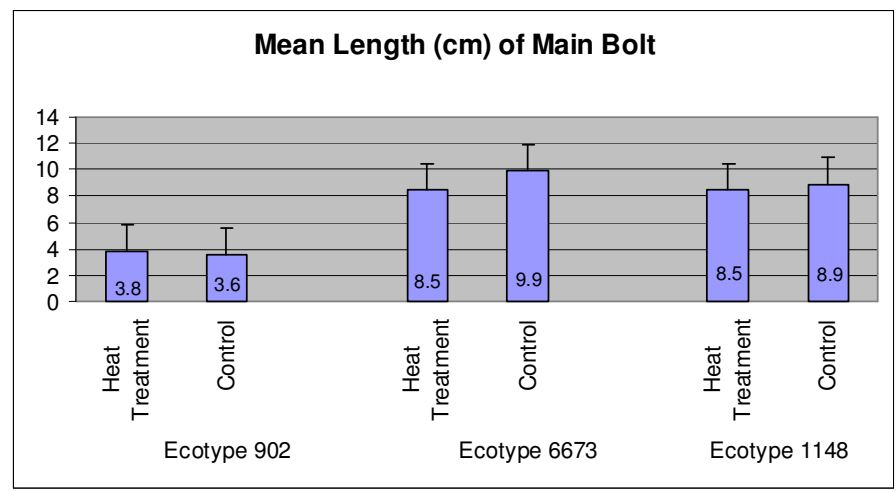

Figure 2. Mean length (+/- SD) of main bolt plotted for heat treated and control plants for each of the three ecotypes.

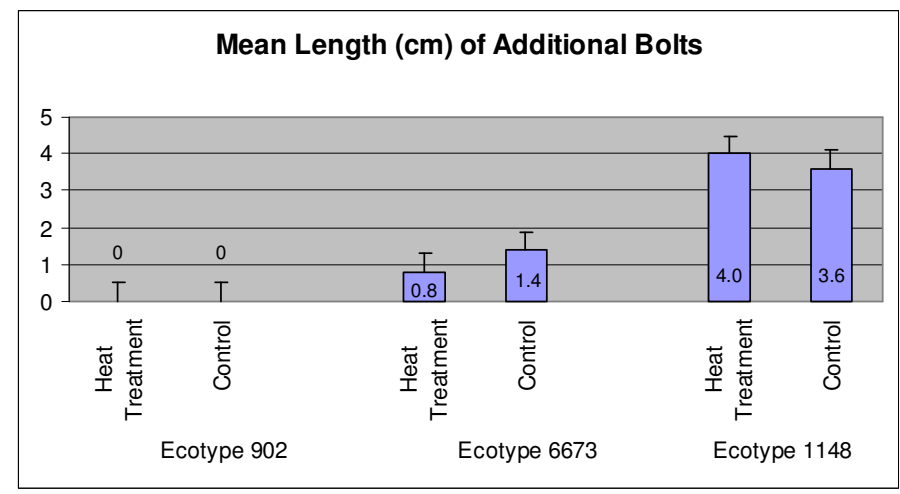

Figure 3. Mean length (+/- SD of additional bolts plotted for heat treated and control plants for each of the three ecotypes.

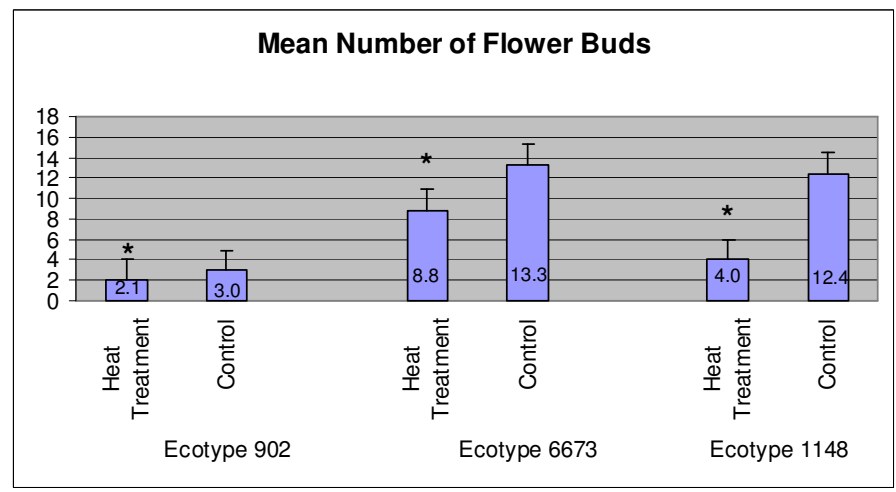

Figure 4. Mean number (+/-SD) of flower buds plotted for heat treated and control plants for each of the three ecotypes. 


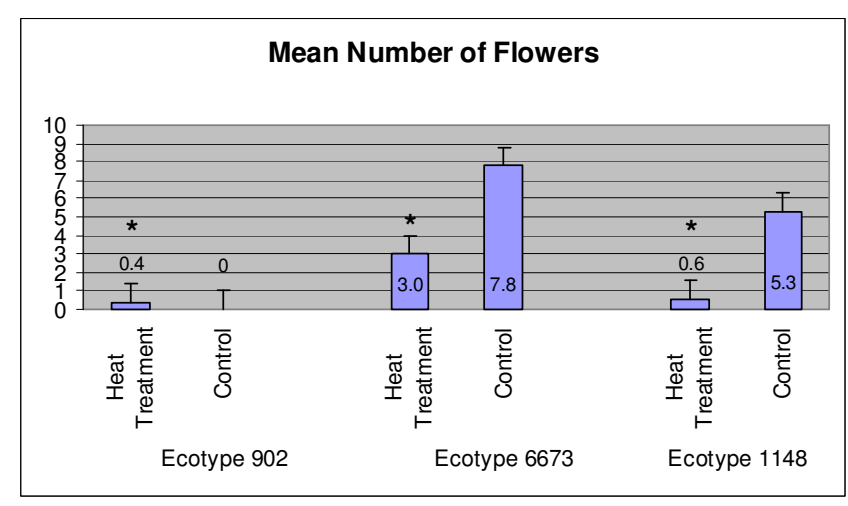

Figure 5. Mean number (+/- SD) of flowers plotted for heat treated and control plants for each of the three ecotypes.

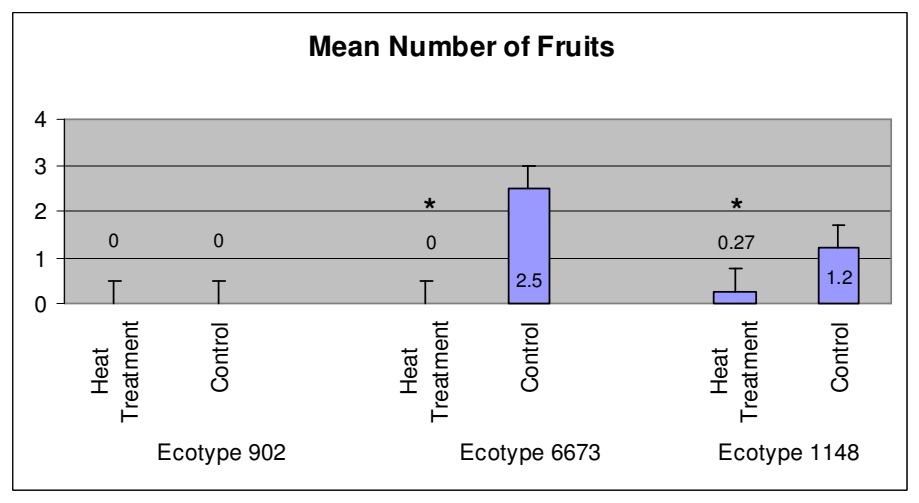

Figure 6. Mean number (+/- SD) of fruits plotted for heat treated and control plants for each of the three ecotypes.

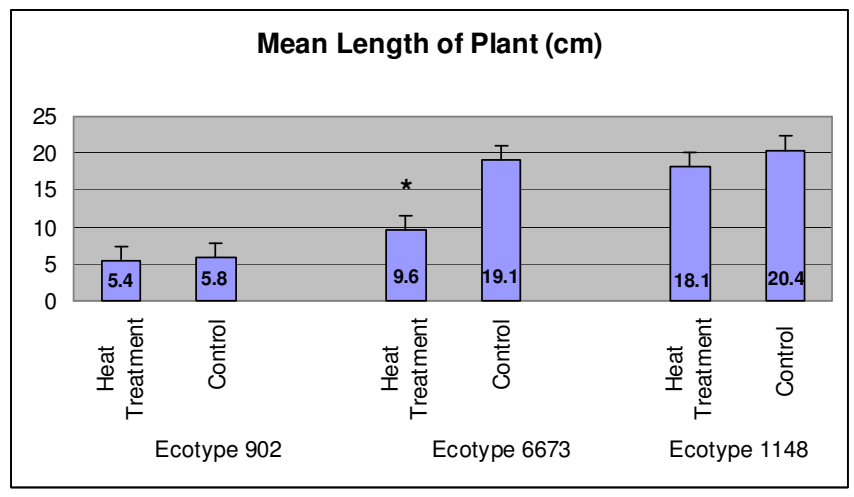

Figure 7. Mean length (+/- SD) of plant for heat treated and control plants for each of the three ecotypes.

\section{Statistical analysis}

One-way ANOVAs were performed for each of the six parameters (number of rosette leaves, length of main bolt, length of additional bolts, number of flower buds, 
number of flowers and number of fruit) in order to determine whether overall plant growth and reproductive development varied significantly between heat stressed and control plants for each of the three ecotypes.

If the ANOVA resulted in a significant P-value, Post Hoc testing was conducted in order to determine which ecotype showed significant difference between heat stressed and control plants.

The percent change between heat and control plants within each of the three ecotypes was additionally calculated for each parameter (Table 2).

Li et al. (1998) collected data from the growth of 40 Arabidopsis ecotypes from a wide range of altitudes and latitudes. They determined, by performing multiple regressions involving both latitude and altitude for the 40 test subjects, that altitudinal differences between ecotype sites were insignificant. Since I do not have a robust data set for altitude ( $n=3$, one altitude associated with each of the three ecotypes), I cannot determine significance via regression analysis. I will therefore not discus altitude as a factor which may affect growth parameters, and will take only latitudinal differences into consideration when projecting heat stress across a (latitudinal) cline.

Table 2. Summary of statistical analysis for each parameter

\begin{tabular}{|c|c|c|}
\hline Rosette Leaves & & \\
\hline $\begin{array}{c}\text { Ecotype } \\
902 \\
6673 \\
1148\end{array}$ & $\begin{array}{c}\% \text { change } \\
-24 \% \\
-47 \% \\
-43 \%\end{array}$ & $\begin{array}{l}\text { P-value } \\
<.05 \\
<.001 \\
<.001\end{array}$ \\
\hline $\begin{array}{c}\text { Main Bolt } \\
\text { Ecotype } \\
902 \\
6673 \\
1148\end{array}$ & $\begin{array}{l}\% \text { change } \\
+.06 \% \\
-.14 \% \\
-.04 \%\end{array}$ & $\begin{array}{l}\text { P-value } \\
\text { No significant difference } \\
\text { No significant difference } \\
\text { No significant difference }\end{array}$ \\
\hline $\begin{array}{c}\text { Additional Bolts } \\
902 \\
6673 \\
1148\end{array}$ & $\begin{array}{c}\% \text { change } \\
0 \% \\
-.40 \% \\
+.08 \%\end{array}$ & $\begin{array}{l}\text { P-value } \\
\text { No significant difference } \\
\text { No significant difference } \\
\text { No significant difference }\end{array}$ \\
\hline $\begin{array}{c}\text { Flower Buds } \\
902 \\
6673 \\
1148\end{array}$ & $\begin{array}{l}\% \text { change } \\
-30 \% \\
-34 \% \\
-68 \%\end{array}$ & $\begin{array}{l}P \text {-value } \\
\quad<.05 \\
<.01 \\
<.001\end{array}$ \\
\hline $\begin{array}{c}\text { Flowers } \\
902 \\
6673 \\
1148\end{array}$ & $\begin{array}{c}\% \text { change } \\
\text { See below }{ }^{1} \\
-62 \% \\
-87 \%\end{array}$ & $\begin{array}{l}P \text {-value } \\
<.001 \\
<.001 \\
<.001\end{array}$ \\
\hline $\begin{array}{l}\text { Fruit } \\
902 \\
6673 \\
1148\end{array}$ & $\begin{array}{c}\% \text { change } \\
0 \% \\
-100 \% \\
-77 \%\end{array}$ & $\begin{array}{c}P \text {-value } \\
\text { No significant difference } \\
<.001 \\
=.05\end{array}$ \\
\hline
\end{tabular}

${ }^{1}$ Heat stressed showed a mean of 8 while the control produced 0 flowers. 


\section{Results and discussion}

This study examined the ecotypic variation in plant growth and development with respect to the number of rosette leaves, the length of the main bolt, the number of additional bolts, the number of flower buds, the number of flowers, and the number of fruits produced at the end of a 35-day growth cycle.

Data clearly indicate a significant difference between heat and control groups within each of the three ecotypes with respect to the number of rosette leaves, the number of flower buds, the number of flowers, and the number of fruits produced.

All three ecotypes showed no significant difference between heat stressed and control plants with respect to the length of the main bolt and the number of additional bolts produced. This stands to reason as niether the bolts are neither reproductive nor a major photosynthetic site.

\section{Ecotype 902}

Ecotype 902 is the most southern of the three ecotypes with a latitude and longitude of N 15, W 23 (Table 1). Ecotype 902 is native to the Cape Verde Islands, an archipelago in the North Atlantic Ocean just off the coast of western Africa. August to October is the only time frame routinely receiving rainfall; otherwise the Cape Verde Islands are relatively dry. Temperature ranges from $22{ }^{\circ} \mathrm{C}$ in February up to $27^{\circ} \mathrm{C}$ in September.

Consistently, ecotype 902 had the smallest percent change between heat stressed and control plants among all six parameters tested, compared to heat and control plants of 1148 and 6673 (Table 2). However, there were still significant findings with respect to the number of rosette leaves $(\mathrm{P}=<.05)$, the number of flower buds $(\mathrm{P}=<.05)$, and the number of flowers produced $(\mathrm{P}=<.001)$. In spite of this statistical significance, while both heat and control 902 plants produced flower buds, the control 902 plants produced neither flowers nor fruits. Although the heat stressed 902 plants had modest flower production, they never developed into fruits. As a result, neither control nor heat stressed 902 plants produced seeds. Therefore, since heat was applied to only one set of 902 plants, heat was apparently not the only factor affecting the reproductive success of this ecotype.

\section{Ecotype 6673}

Ecotype 6673 is the median latitude representative with a latitude and longitude of $\mathrm{N}$ 38, W 92 (Table 1). This corresponds to Columbia, Missouri, a Midwestern city with temperature ranging from $-1.3{ }^{\circ} \mathrm{C}$ in January to $25.4{ }^{\circ} \mathrm{C}$ in July and the heaviest rainfall occurring from May to August.

Control plants of ecotype 6673 overwhelmingly grew better than heat stressed plants with respect to the number of rosette leaves $(\mathrm{P}=<.001)$, the number of flower buds $(\mathrm{P}=<.01)$, the number of flowers $(\mathrm{P}=<.001)$ and the number of fruits produced $(\mathrm{P}=<.001)$. Heat stressed 6673 plants produced no fruits, demonstrating that elevated heat adversely affected reproduction in this ecotype. Control 6673 plants performed better than heat stressed plants for all six parameters, however only four of the six were deemed statistically significant. Moreover, control 6673 plants produced 34\% more flower buds, $62 \%$ more flowers, and $100 \%$ more fruits than the heat treated 6673 plants (Table 2). 


\section{Ecotype 1148}

Ecotype 1148 is the Northernmost of the three ecotypes, with a latitude and longitude of N 58, E 23 (Table 1). Located within the former Union of Soviet Socialist Republics, this area receives its heaviest rainfall from June to September and ranges in temperature from $-6.1{ }^{\circ} \mathrm{C}$ in February to $17.3^{\circ} \mathrm{C}$ in July.

Control plants did significantly better than heat stressed plants with respect to the number of rosette leaves $(\mathrm{P}=<.001)$, the number of flower buds $(\mathrm{P}=<.001)$, the number of flowers $(\mathrm{P}=<.001)$, and the number of fruits $(\mathrm{P}=.05)$. With respect to reproductive ecology, control 1148 plants produced $68 \%$ more flower buds, $87 \%$ more flowers, and $77 \%$ more fruits than heat stressed 1148 plants (Table 2).

All climate information was obtained from a combination of the following two web sites: http://www.britannica.com and http://www.worldclimate.com/.

\section{Effects of latitude}

It stands to reason that since ecotype 902 is the least Northern latitude with respect to the other two ecotypes that it was the least effected by heat when comparisons were made between heat stressed and control plants. However, since ecotype 902 had growth far less than published growth means for this ecotype, conditions other than heat have apparently negatively impacted its growth and development.

Since ecotype 902 is from a region that receives little rainfall and all plants were watered equally throughout this experiment, it is possible that ecotype 902 received too much water. Additionally, arid regions are typically associated with low humidity levels. The optimum scope of humidity for Arabidopsis growth is reported to range from $25 \%-75 \%$ which is why I chose to maintain humidity at $55 \%$, however ecotype 902 may do better in an environment with $25 \%$ humidity.

As the Northernmost ecotype of the three, ecotype 1148 was understandably the most affected by heat. The highest percent change regarding flower buds and flower production was in fact found in control 1148 plants, with heat stressed plants doing 68\% and $87 \%$ poorer than control plants. Since reproductive success is a mark of fitness, control 6673, the mid-latitude representative ecotype, did the best with the highest number of fruits produced of any ecotype for both heat stressed and control.

\section{Overall plant size}

According to TAIR, ecotype 902 averages 30cm, ecotype 6673 averages $25-35 \mathrm{~cm}$, and ecotype 1148 averages $25-35 \mathrm{~cm}$ (Table 1). Experimental mean plant sizes were all less than the aforementioned database plant lengths (Figure 7). Ecotype 6673 was the only ecotype to show a significant overall growth difference between heat stressed and control plants $(\mathrm{P}=<.001)$. Ecotype 902 showed the most reduced overall plant growth for both heat stressed and control plants with an $82 \%$ decrease in growth from the database mean for this plant. Taken as a whole, control plants faired better than heat stressed plants for all three ecotypes with, ecotype 6673 on average growing $50 \%$ more than heat treated 6673. 


\section{Future studies}

Since the seed is an integral stage in the development of higher plants, it would be valuable to determine the number of viable propagules produced within each fruit in order to make a comparison between heat stressed and control plants as this information could be directly related to the survival of the species.

Pollination biology is another aspect of Arabidopsis development that could provide information as to how higher plants may be affected by augmenting global temperatures. Arabidopsis has a striking and delicate stigma morphology which would facilitate a visual comparison of any structural distortions between heat stressed and control plants. Potential alterations in stigma cytochemsitry due to elevated temperature are another area of prime importance in successful pollination and germination of compatible pollen tubes leading to fertilization.

Estimation of pollen viability has been published for a great many species including several economically valuable food plants. There exists a gap in the literature, however, with respect to differences in pollen viability between heat stressed and optimally grown plants.

Koornneef et al. (1983) identified the four recessive homeotic mutations that disrupt the development of flowers in Arabidopsis. These four mutations: agamous, apetala2, apetala3, and pistillata are further described by Bowman et al. (1989). Since homeotic genes can take the place of another member in a repetitive series, for example, transform sepals into petals, it would be interesting to see how these genes directing flower development are affected by temperatures in excess of optimum.

Finally, the molecular genetics controlling the time of flowering can give insight into the phenotypic variation in natural populations such that agriculturally valuable plant species and the floriculture industry can adapt, if necessary, to a warming climate. Flowering time can give insight into the ecology of plant reproduction. Stinchcombe et al. (2004) found a significant latitudinal cline with respect to flowering time among 70 experimentally grown ecotypes of A. thaliana. Caicedo et al. (2004) showed that epistatic gene interaction between FRIGIDA (FRI) and FLOWERING LOCUS C (FLC), the two genes responsible for flowering time in Arabidopsis, interact in such a way that they both contribute to a latitudinal cline in flowering time. Since flowering time in Arabidopsis has been correlated with fecundity, this will prove a valuable life history trait within Arabidopsis.

\section{Conclusions}

The results clearly indicate a significant difference between heat stressed and control plants for rosette leaf production, flower buds, flowers, and fruits with heat treatment resulting in a reduction of the aforementioned parameters observed.

A decrease in leaf biomass was noted across all heat treated plants. Decreased leaf biomass may lead to a reduced surface area for reactions, such as photosynthesis and transpiration. In turn, this reduction may lead to an overall decrease in plant size. In fact, all three sets of heat treated plants not only had less leaf production, but also had reduced overall growth compared to control plants.

It is often noted that plants typical of low latitudes require less exposure to cold temperatures before flowering. This overall reduction in vernalization may become more apparent in plants of varying latitudes, as global temperatures increase. 
An increase in growth is often associated with a reduction in reproduction. This tradeoff was not noted in heat treated plants as they were reduced in size and produced little or no fruits demonstrating that both growth and reproduction were negatively affected. While temperature and humidity, water, soil composition, and light were all regulated throughout the experiment, heat may not be the only variable affecting the outcome of this experiment. Nonetheless, data indicates that heat it is a significant factor in the reduction of growth and development in Arabidopsis thaliana.

In summation, as global temperature increases, plants and animals will more significantly exhibit an increased sensitivity on an ecosystem level; however the research findings referred to throughout clearly indicate that cumulative microclimate and species alterations will have far reaching effects. And while all interactions at the population level and up may be impossible to definitively project as a result of heat stress effects, much literature suggests raising temperatures $3-5{ }^{\circ} \mathrm{C}$ significantly alters species distributions and abundances [7] [19] [30], and most likely will cause widespread changes in food-web and ecosystem structuring [10] [5] [19]. Shifts in dominant vegetation due to global temperature increases [10] [25] may lead to a shift in both inter- and intraspecies competition, for example.

Changes in plant physiology and development [18] [26] [17] [20] [9], all ways of dealing with temperature increase, greenhouse gas increases, ozone depletion, higher incidence of UV exposure, and loss of soil moisture, may not be an option for many species as not all plants have the genetic ability to respond via changes in physiology. As a result, their abundance will be reduced as they are out-competed by those able to acclimate. Those plants without the ability to respond genetically will experience reduced fitness as they trade-off reproduction in order to counter long-term consequences of heating.

The research presented here provides a basic framework for describing variation in plant growth and development as a direct result of heat stress. It additionally serves to project these findings across a latitudinal gradient to determine if plants growing at varying latitudes are differentially affected by temperature increases as well as to apply the findings to agronomic practices. Plant growth and development, global temperatures, alterations to the physical and chemical characteristics of the landscape, and range shifts can all impact the forestry business and the agricultural industry in terms of crop plants and productivity.

Acknowledgements. I'd like to thank Dr. Michael Zimmerman for valuable advice, comments, and discussions; Dr. Richard Schlesinger for his help with the statistical analysis and interpretation of statistical data; Dr. Lisa Dorn for her guidance and helpful suggestions working with Arabidopsis; and Pace University, Dyson College of Arts and Sciences, Department of Biology and Health Sciences for providing the research site.

\section{REFERENCES}

[1] Betts R.A. (1997): Contrasting Physiological and structural vegetation feedbacks in climate change simulations. - Nature 387: 796-799.

[2] Bisseling T., Weigel D. (2001): Plant development: From cell fate to organ formation. Plant Cell 13: 221-227.

[3] Bowman J.L., Smyth D.R., Meyerowitz E.M. (1989): Genes directing flower development in Arabidopsis. - The Plant Cell 1: 37-52. 
[4] Caicedo A.L., Stinchcombe J.R., Olsen K.M., Schmitt J., Purugganan M.D. (2004): Epistatic interaction between Arabidopsis FRI and FLC flowering time genes generates a latitudinal cline in a life history trait. - P. Natl. Acad. Sci. USA 101: 15670-15675.

[5] Cao M., Woodward F.I. (1998): Dynamic responses of terrestrial ecosystem carbon cycling to global climate change. -Nature 393: 249-252.

[6] Cross R.H., McKay S.A.B., McHughen A.G., Bonham-Smith P.C. (2003): Heat-stress effects on reproduction and seed set in Linum usitatissium L. (flax). - Plant Cell Environ. 26: 1013-1020.

[7] Davis A.J., Jenkinson L.S., Lawton J.H., Shorrocks B., Wood S. (1998): Making mistakes when predicting shifts in species range in response to global warming. - Nature 391: 783786.

[8] Frohnmeyer H., Staiger D. (2003): Ultraviolet-B radiation-mediated responses in plants. Balancing damage and protection. - Plant Physiol. 133: 1420-1428.

[9] Gray J.E., Holroyd G.H., Van Der Lee F.M., Bahrami A.R., Sijmons P.C., Woodward F.I., Schuch W., Hetherington A.M. (2000): The HIC signaling pathway links $\mathrm{CO}_{2}$ perception to stomatal development. - Nature 408: 713-716.

[10] Harte J., Shaw R. (1995): Shifting dominance within a montane vegetation community: Results of a climate-warming experiment. - Science 267: 876-880.

[11] Intergovernmental Panel on Climate Change (IPCC) (2001): Climate change 2001: the scientific basis. Contribution of working group I to the second assessment report of the IPCC. - Cambridge University Press, New York.

[12] Koornneef M., Alonso-Blanco C., Peeters A.J., Soppe W. (1998): Genetic control of flowering time in Arabidopsis. - Annu. Rev. Plant Physiol. Plant Mol. Biol. 49: 345-370.

[13] Li B., Suzuki J., Hara T. (1998): Latitudinal variation in plant size and relative growth rate in Arabidopsis thaliana. Oecologia 115: 293-301.

[14] Loik M.E., Redar S.P., Harte J. (2000): Photosynthetic responses to a climate-warming manipulation for contrasting meadow species in the Rocky Mountains, Colorado, USA. Funct. Ecol. 14: 166-175.

[15] McCarty J.P. (2001): Ecological consequences of recent climate change. - Conserv. Biol. 15: 320-331.

[16] Menzel A., Fabian P. (1999): Growing season extended in Europe. - Nature 397:659.

[17] Morgan J.A,. Lecain D.R., Mosier A.R., Milchunas D.G. (2001): Elevated $\mathrm{CO}_{2}$ enhances water relations and productivity and affects gas exchange in $\mathrm{C}_{3}$ and $\mathrm{C}_{4}$ grasses of the Colorado shortgrass steppe. - Glob. Change Biol. 7: 451-466.

[18] Peet M.M., Sato S., Gardner R.G. (1998): Comparing heat stress effects on male-fertile and male sterile tomatoes. - Plant Cell Environ. 21: 225-231.

[19] Petchey O.L., McPhearson T.P., Casey T.M., Morin P.J. (1999): Environmental warming alters food-web structure and ecosystem function. - Nature 402: 69-72.

[20] Porch T.G., Jahn M. (2001): Effects of high-temperature stress on microsporogenesis in heat-sensitive and heat-tolerant genotypes of Phaseolus vulgaris. - Plant Cell Environ. 24: 723-731.

[21] Prasad P.V.V., Boote K.J., Allen J.R. L.H., Thomas J.M.G. (2002): Effects of elevated temperature and carbon dioxide on seed-set and yield of kidney bean (Phaseolus vulgaris L.) - Glob. Change Biol. 8: 710-721.

[22] Reekie E.G., Reekie J.Y.C. (1991): The effect of reproduction on canopy structure, allocation and growth in Oenothera biennis. - J. Ecol. 79: 1061-1071.

[23] Roeder A.H.K., Yanofsky M.F. (2005): Fruit development in Arabidopsis. In: American Society of Plant Biologists. The Arabidopsis Book. - Rockville (MD) p 1-50.

[24] Saavedra F., Inouye D.W., Price M.V., Harte J. (2003): Changes in flowering and abundance of Delphinium nuttallianum (Ranunculaceae) in response to a subalpine climate warming experiment. - Glob. Change Biol. 9: 885-894.

[25] Sanford E. (1999): Regulation of keystone predation by small changes in ocean temperature. - Science 283: 2095-2097. 
[26] Sato S., Peet M.M., Thomas J.F. (2000): Physiological factors limit fruit set of tomato (Lycopersicon esculentum Mill.) under chronic, mild heat stress. - Plant Cell Environ. 23: 719-726.

[27] Schimel D.S., House J.I., Hibbard K.A., Bousquet P., Ciais P., Peylin P., Braswell B.H., Apps M.J., Baker D., Bondeau A., Canadell J., Churkina G., Cramer W., Denning A.S., Field C.B., Friedlingstein P., Goodale C., Heimann M., Houghton R.A., Melillo J.M., Moore B., Murdiyarso D., Noble I., Pacala S.W., Prentice I.C., Raupach M.R., Rayner P.J., Scholes R..J, Steffen W..L, Wirth C. (2001): Recent patterns and mechanisms of carbon exchange by terrestrial ecosystems. - Nature 414: 169-172.

[28] Stinchocome J.R., Weinig C., Ungerer M., Olsen K.M., Mays C., Halldorsdottir S.S., Purugganan M.D., Schmitt J. (2004): A latitudinal cline in flowering time in Arabidopsis thaliana modulated by the flowering time gene FRIGIDA. - P. Natl. Acad. Sci. USA 101: $4712-4717$.

[29] Torabinejad J., Caldwell M.M. (2000): Inheritance of UV-B tolerance in seven ecotypes of Arabidopsis thaliana L. Heynh. And their F1 hybrids. - Am. Genet. Assoc. 91: 228233.

[30] Walther G.R., Post E., Convey P., Menzel A., Parmesan C. Beebee T.J.C., Fromentin J.M., Hoegh-Guldberg O., Bairlein F. (2002): Ecological responses to recent climate change. - Nature 416: 389-395. 